\title{
USIA MENARCHE PEREMPUAN INDONESIA SEMAKIN MUDA: HASIL ANALISIS RISKESDAS 2010
}

\section{Evidence Of Downward Secular Trend In Age At Menarche Among Indonesian Women: Secondary Data Analisis Of Riskesdas 2010}

\author{
Sudikno $^{1 *}$, Sandjaja $^{2}$ \\ ${ }^{1}$ Pusat Penelitian dan Pengembangan Upaya Kesehatan Masyarakat, Badan Litbangkes \\ ${ }^{2}$ Dewan Pimpinan Pusat Persatuan Ahli Gizi (DPP Persagi), Jakarta \\ *Email: onkidus@gmail.com
}

Naskah masuk 17 Desember 2019; review 18 Desember 2019; disetujui terbit 31 Desember 2019

\begin{abstract}
Background: A downward trend in age at menarche (AAM) has been leveling-off in industrialized countries. However, downward trends were still observed in developing countries.

Objective: The aim was to verify secular trend of AAM among Indonesian women and its associated factors.

Methods: Data used were from Baseline Health Research (Riskesdas) 2010, a cross-sectional nationwide survey. Samples included were 79,026 women aged 10-59 years. History of menarche, socio-demographic variables, weight, height were taken. Descriptive and bivariate analysis were applied to measure proportion, central tendency measures.

Results: Among adolescent 10-19years, overall proportion of menarche was $78.6 \%$, ranging from $42.8 \%$, $96.2 \%, 99.6 \%$ at age 12, 15, 18 years respectively. The overall mean AAM was 12.96 years. AAM was significantly younger in urban than rural areas. BMI was significantly lower among adolescense not experienced menarche yet than experienced menarche. AAM was younger in urban areas, higher socioeconomic status, and varied among seven regions.

Conclusions: Nutritional status was a significant factor associated with AAM. A downward trend in AAM was observed in Indonesian women.
\end{abstract}

Key words: menarche, secular trend, body mass index, Indonesian woman

\begin{abstract}
Abstrak
Latar belakang: Tren penurunan usia pada menarche telah meningkat di negara-negara industri. Namun, tren penurunan masih diamati di negara-negara berkembang.

Tujuan: untuk memverifikasi tren sekuler usia menarche di kalangan perempuan Indonesia dan faktor-faktor terkaitnya.

Metode: Data yang digunakan berasal dari Riskesdas 2010, survei nasional dengan desain cross-sectional. Sampel yang dianalisis adalah 79.026 perempuan berumur 10-59 tahun. Variabel yang dikumpulkan meliputi: riwayat menarche, sosio-demografis, berat badan, tinggi badan. Analisis deskriptif dan bivariat digunakan untuk mengukur proporsi, ukuran kecenderungan sentral.

Hasil: Di antara remaja 10-19 tahun, proporsi keseluruhan menarche adalah 78,6 persen, mulai dari 42,8 persen, 96,2 persen, 99,6 persen pada masing-masing umur 12, 15, dan 18 tahun. Rata-rata keseluruhan usia menarche adalah 12,96 tahun. Usia menarche secara signifikan lebih muda di daerah perkotaan daripada pedesaan. IMT secara signifikan lebih rendah di antara remaja yang belum mengalami menarche dibandingkan dengan remaja yang sudah mengalami menarche. Usia menarche lebih muda di daerah perkotaan, status sosial ekonomi yang lebih tinggi, dan bervariasi di antara tujuh daerah.

Kesimpulan: Status gizi adalah faktor signifikan yang terkait dengan usia menarche. Terjadi Tren penurunan usia menarche pada perempuan di Indonesia.
\end{abstract}

Kata kunci: menarche, tren sekuler, indeks massa tubuh, perempuan Indonesia 


\section{PENDAHULUAN}

Menarche, periode menstruasi pertama, adalah biomarker penting dalam kehidupan reproduksi perempuan. ${ }^{1,2}$ Hal ini berhubungan dengan tingkat status kesehatan yang mempengaruhi kesejahteraan perempuan di tahap kehidupan selanjutnya. ${ }^{3}$ Usia saat menarche semakin mendapat perhatian karena beberapa penelitian menunjukkan adanya penurunan usia menarche. ${ }^{3,4}$

Usia menarche pada pertengahan abad ke-19 berkisar antara 16-17 tahun. ${ }^{5}$ Berdasarkan penelitian dari 67 negara yang diterbitkan antara 1960-an dan 1990-an, usia rata-rata saat menarche dilaporkan 13,53 tahun (standar deviasi $\pm 0,98) .{ }^{2}$ Tren ini menandakan tingkat penurunan 3 hingga 4 bulan per dekade, walaupun di beberapa negara Eropa ${ }^{5}$, Amerika Serikat dan $\mathrm{Asia}^{3}$ masih berlangsung. Sebuah studi nasional di Amerika Serikat menunjukkan bahwa usia menarche telah turun dari 12,75 tahun pada 1960-an menjadi 12,5 tahun pada 1990-an dan lagi menjadi 12,3 tahun pada 2000-an. ${ }^{6}$

Studi yang dilakukan pada abad ke-20 mendokumentasikan faktor-faktor yang terkait dengan usia saat menarche, seperti: iklim (khususnya suhu tahunan rata-rata), etnis, status sosial, tempat tinggal perkotaan atau pedesaan, aktivitas fisik, pendidikan, stimulasi seksual, perumahan, warisan, dan status kesehatan. ${ }^{7}$

Analisis usia menarche pada data Riskesdas 2010 belum dilakukan. Tujuan penelitian ini adalah untuk memverifikasi tren sekuler usia pada menarche di kalangan perempuan Indonesia dan faktor-faktor yang terkait.

\section{METODE}

Data yang digunakan dalam analisis ini adalah Riskesdas 2010. Riskesdas 2010 merupakan penelitian yang dilaksanakan oleh Badan Litbang Kesehatan dengan disain penelitian cross-sectional. Populasi adalah rumah tangga (RT) di Indonesia pada tahun 2010. Kerangka sampel Riskesdas 2010 adalah RT hasil listing

\footnotetext{
* Corresponding author

(Email: onkidus@gmail.com)
}

Sensus Penduduk 2010 dan sampel Riskesdas 2010 yang pilih adalah rumah tangga terpilih pada 2800 blok sensus (BS) yang sudah ditetapkan sebesar 25 RT setiap BS yang diambil secara sistematis. Jumlah sampel rumah tangga yang direncanakan adalah sebesar 70.000 RT. Pengumpulan data dilakukan bulan Juli sampai dengan Agustus 2010. Hasil pengumpulan data Riskesdas 2010 mencapai 69.300 rumah tangga dari 2798 blok sensus yang berhasil dikunjungi.

Jumlah sampel yang dianalisis adalah 79.026 perempuan berumur 10-59 tahun. Riwayat menarche, variabel sosio-demografis dikumpulkan dari sampel oleh enumerator dengan latar belakang ilmu kesehatan menggunakan kuesioner.

Variabel yang dikumpulkan meliputi: berat badan yang diukur dengan timbangan digital, tinggi badan diukur dengan microtoise. Selanjutnya dilakukan perhitungan Indeks massa tubuh (IMT) dihitung dari berat $(\mathrm{Kg})$ yang dibagi dengan kuadrat tinggi badan (meter). Analisis deskriptif dan bivariat digunakan untuk mengukur proporsi, ukuran kecenderungan sentral.

\section{HASIL}

Jumlah sampel yang dianalisis adalah 79.026 perempuan yang berumur 10-59 tahun. Gambar 1 menunjukkan proporsi menarche pada remaja umur 10-19 tahun di wilayah perkotaan dan perdesaan. Proporsi menarche pada remaja antara umur 10-15 tahun lebih banyak di perkotaan dibandingkan di perdesaan. Proporsi menarche remaja antara umur 16-19 tahun tampak hampir sama antara perkotaan dan perdesaan. Di antara remaja 10-19 tahun, proporsi keseluruhan menarche adalah 78,6 persen di perdesaan dan perkotaan. Proporsi menarche di perdesaan dan perkotaan pada umur 12 tahun, 15 tahun, dan 18 tahun masingmasing secara berurutan adalah 42,8 persen, 96,2 persen, dan 99,6 persen.

(C) National Institute of Health Research and Development ISSN: 2354-8762 (electronic); ISSN: 2087-703X (print) 


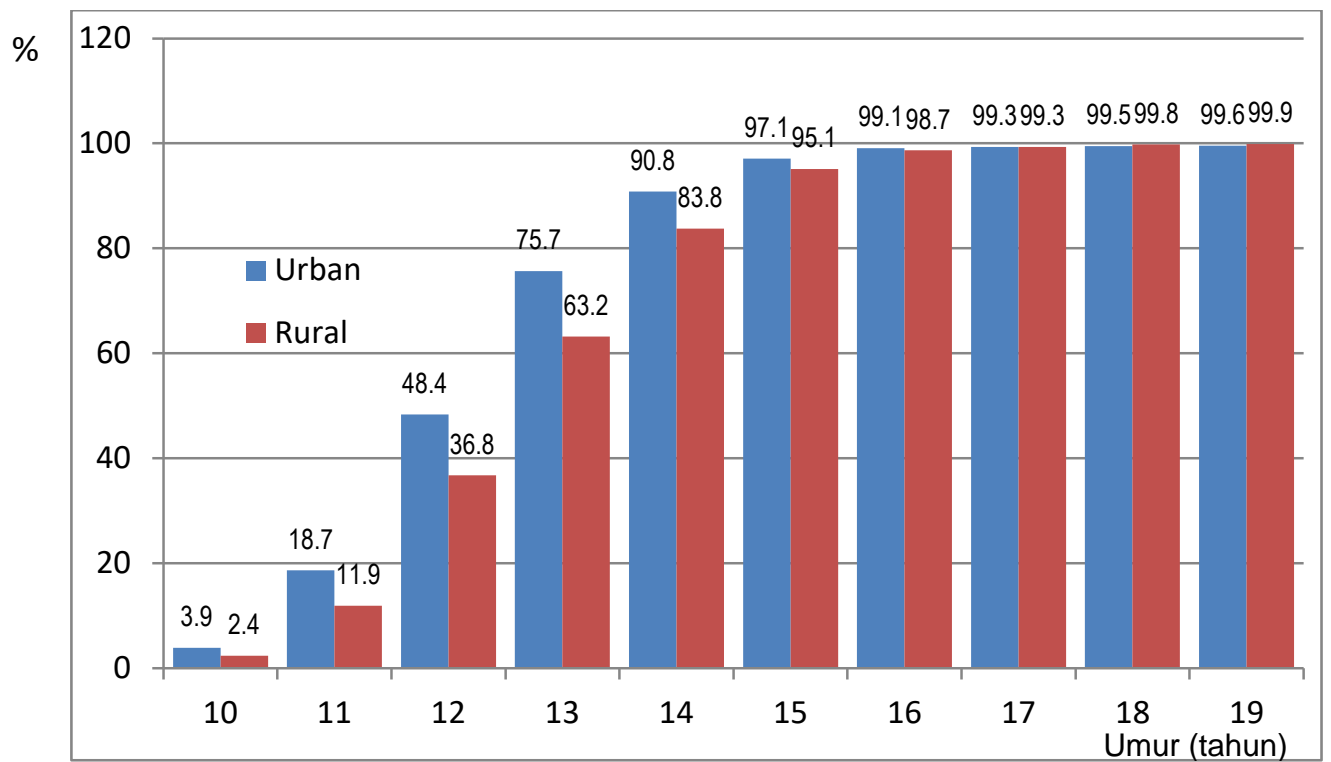

Gambar 1. Proporsi menarche pada remaja 10-19 tahun menurut daerah

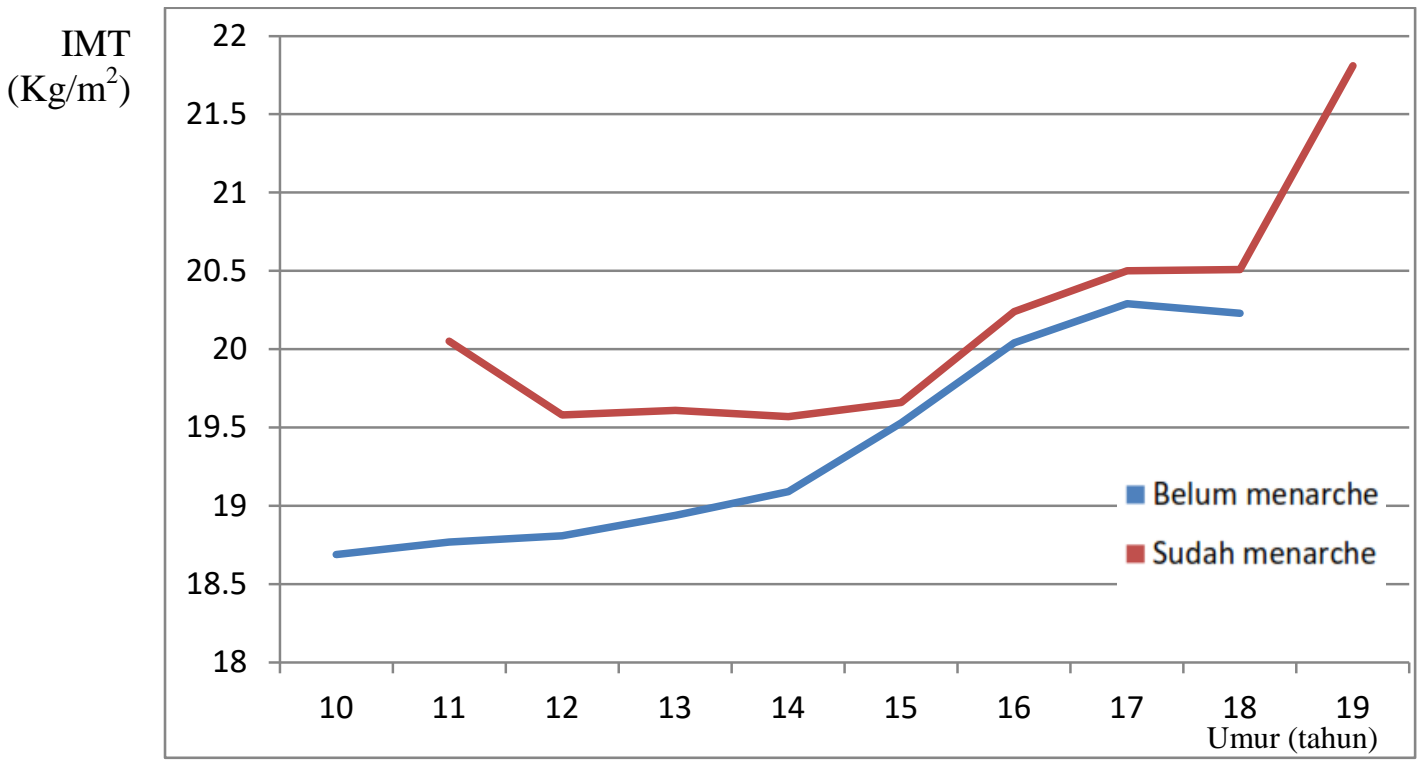

Gambar 2. Rata-rata indeks massa tubuh (IMT) menurut kejadian menarche dan umur

Rata-rata keseluruhan usia menarche adalah 12,96 tahun (Gambar 2). Usia menarche secara signifikan lebih muda di daerah perkotaan dibandingkan dengan di perdesaan (Gambar 3). Indeks massa tubuh (IMT) secara signifikan lebih rendah di antara remaja yang belum mengalami menarche dibandingkan dengan remaja yang sudah mengalami menarche (Gambar 


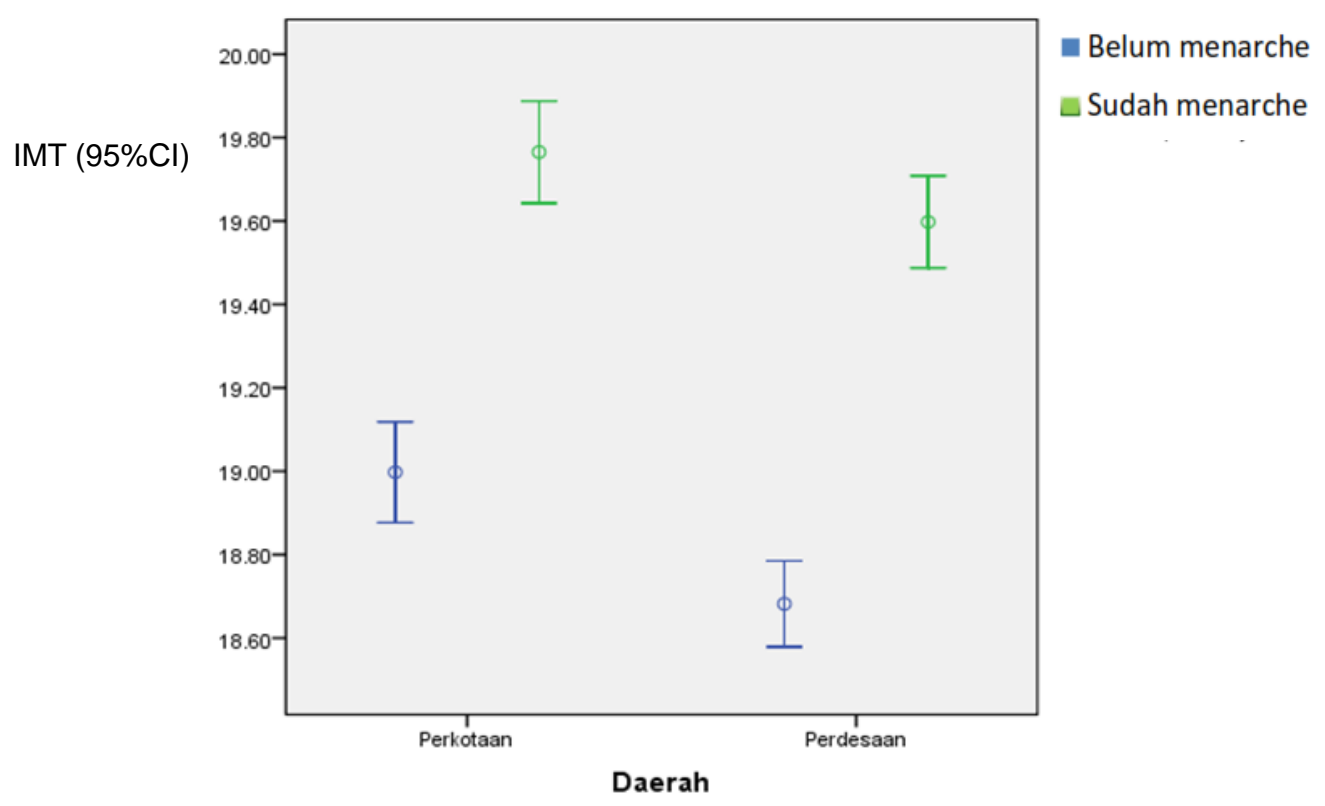

Gambar 3. Rata-rata indeks massa tubuh (IMT) menurut kejadian menarche dan daerah

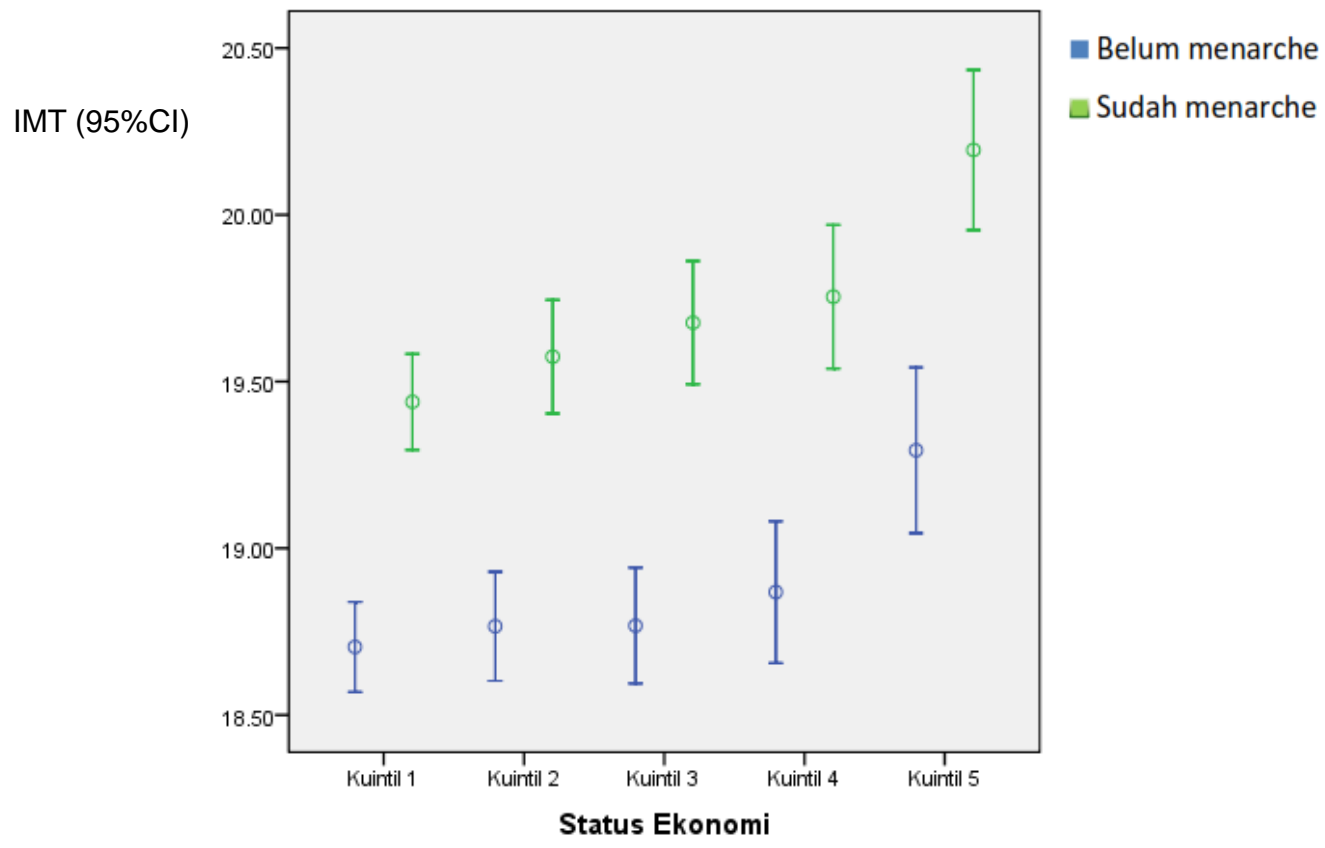

Gambar 4. Rata-rata indeks massa tubuh (IMT) menurut kejadian menarche dan kuintil SES

Di antara perempuan berusia 20-59 tahun, ada kecenderungan penurunan usia menarche. Ratarata kohor kelahiran usia menikah 1955-59, 1960-64, 1965-69, 1970-74, 1975-79, 1980-
1984, 1985-1989, 1990-94 masing-masing adalah 14,14 tahun, 14,14 tahun, 14,09 tahun, 13,85 tahun, 13,75 tahun, 13,71 tahun, 13,58 tahun, dan 13,54 tahun. 
Usia menarche lebih muda pada subjek dengan status sosial ekonomi yang lebih tinggi (Gambar 4 dan Gambar 5). Dari Gambar 6 tampak bahwa usia menarche bervariasi di antara tujuh region (Sumatera, Jawa-Bali, Nusa Tenggara, Kalimantan, Sulawesi, Maluku, dan Papua).

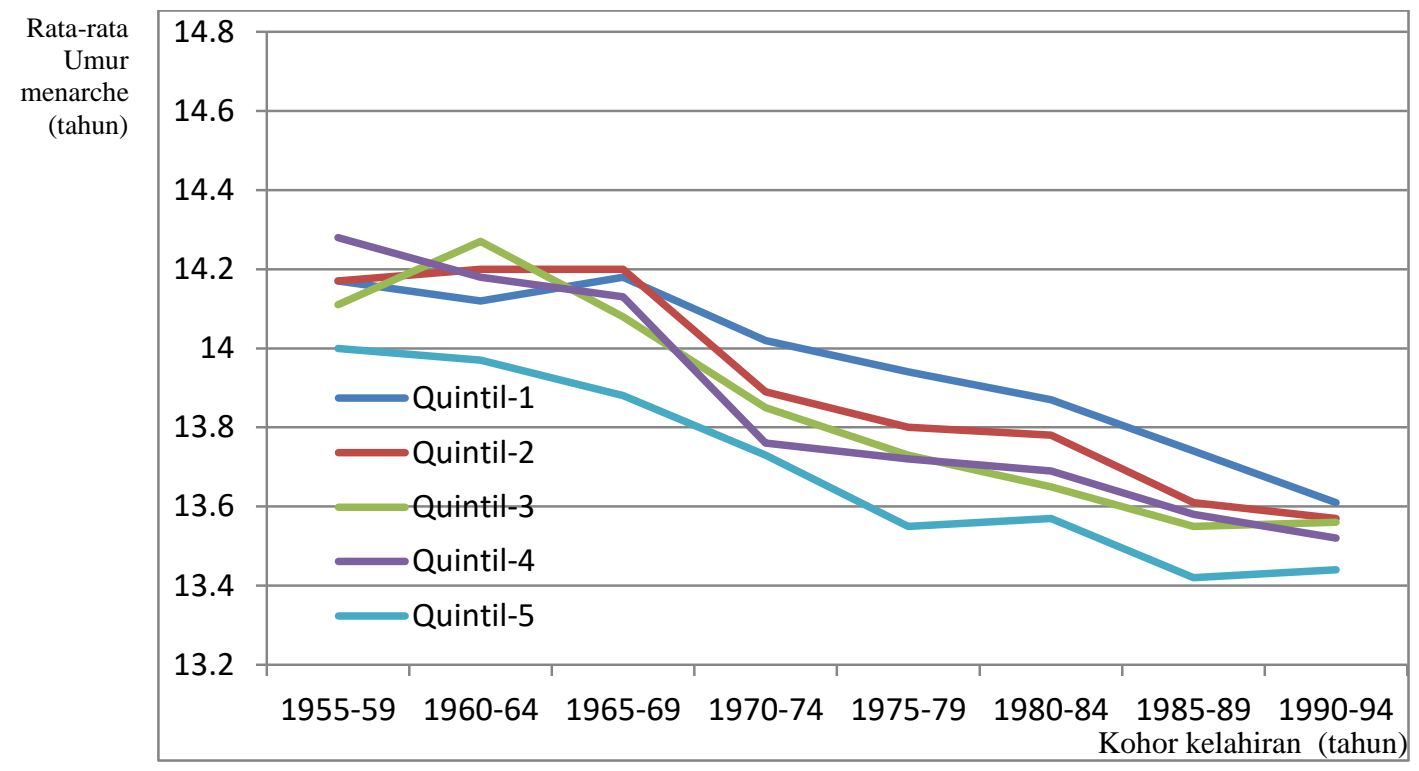

Gambar 5. Rata-rata umur menarche menurut kuintil SES dan kohor kelahiran

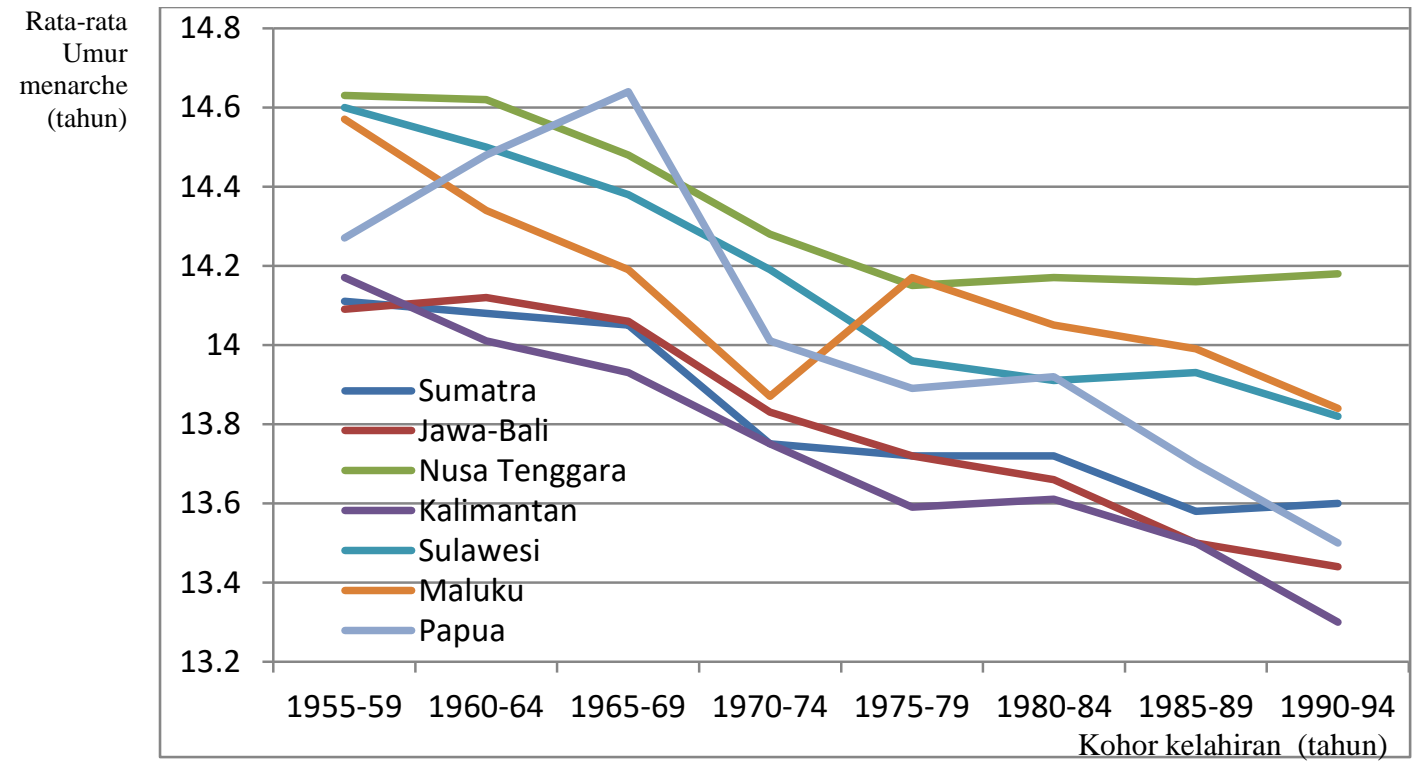

Gambar 6. Rata-rata umur menarche menurut 7 region dan kohor kelahiran

\section{PEMBAHASAN}

Dalam penelitian ini didapatkan usia rata-rata menarche adalah 12,96 tahun. Rata-rata ini lebih rendah dibandingkan penelitian Koo, dkk.(2002) di Ontario yang melaporkan usia rata-rata menarche adalah 13,6 tahun $^{8}$ dan di Norwegia $^{9}$ yaitu 13,1 tahun. Sementara itu pada penelitian sebelumnya di Kota Quebec ditemukan rata-rata usia menarche sebesar 12,1 $\operatorname{tahun}^{10}$ dan penelitian Al-Sahab dkk. (2010) mendapatkan rata-rata usia saat menarche adalah 12,72 tahun. $^{11}$

Pada populasi Barat, usia saat menarche telah menurun sekitar 0,3 tahun per dekade hingga tahun 1950-an. ${ }^{5,12}$ Menurut Tanner (1989) diperkirakan bahwa selama abad ke-20 usia 
menarche telah turun sekitar 3 bulan per dekade. ${ }^{13}$ Pada anak perempuan Norwegia, usia rata-rata saat menarche dilaporkan di atas 16 tahun pada tahun 1830, padahal sudah stabil sekitar 13 tahun sejak 1940-an..$^{14,15,16}$ Sebaliknya, penelitian dari Denmark dan AS menunjukkan penurunan lebih lanjut dalam usia onset pubertas pada anak perempuan. Perubahan usia saat menarche menunjukkan tren sekuler asimetris dalam waktu perkembangan pubertas. ${ }^{17,18}$

Pada penelitian ini juga mendapatkan hasil bahwa IMT secara signifikan lebih rendah di antara remaja yang belum mengalami menarche dibandingkan dengan remaja yang sudah mengalami menarche. Penelitian Bratke, dkk. (2017) menunjukkan bahwa usia menarche berhubungan kuat dengan IMT. Hal ini mungkin terkait dengan tempo pertumbuhan yang umum, karena usia rata-rata saat menarche tetap stabil selama dekade terakhir selama periode waktu, sementara prevalensi kelebihan berat badan dan obesitas telah meningkat secara signifikan. ${ }^{9}$

Studi sebelumnya telah menghubungkan menarche awal dengan status berat badan yang lebih tinggi pada masa kanak-kanak ${ }^{19,20}$, dan pada penelitian Adair dkk. (2001) menemukan prevalensi kelebihan berat badan yang lebih tinggi pada anak perempuan dengan menarche sebelum 11 tahun dibandingkan dengan mereka yang menarche setelah usia 14 tahun. ${ }^{3}$ Perbedaan ini tetap sampai dewasa muda, sebagai tindak lanjut dari perempuan muda dengan menarche awal yang menunjukkan IMT lebih tinggi dan ketebalan lipatan kulit yang lebih besar pada usia 21 dan 27 tahun, bila dibandingkan dengan perempuan dengan menarche terlambat. ${ }^{21}$

Penelitian ini juga mendapatkan hasil bahwa usia menarche lebih muda di daerah perkotaan, status sosial ekonomi yang lebih tinggi, dan bervariasi di antara tujuh daerah. Hal ini sesuai dengan hasil penelitian kohor di Amerika yang mendapatkan hasil bahwa ada hubungan yang signifikan antara peningkatan status sosial ekonomi rumah tangga pada remaja kulit hitam dengan usia menarche yang lebih awal, walaupun hubungannya lemah pada remaja kulit putih. $^{22}$
Penelitian Al-Sahab dkk. (2010) mendapatkan hasil bahwa dari semua indikator sosialekonomi, hanya pendapatan yang ditemukan memiliki pengaruh signifikan terhadap usia saat menarche. Penghasilan tinggi dikaitkan dengan usia menarche awal yang lebih rendah. ${ }^{11}$ Dalam studi sebelumnya, status sosial ekonomi yang lebih tinggi meningkatkan status gizi dan mengakibatkan menarche lebih dini. ${ }^{2,5}$ Hal ini selanjutnya dibenarkan oleh teori Frisch \& McArthur (1974) yang menyatakan proporsi lemak tubuh $(17 \%-22 \%)$ mungkin diperlukan untuk memicu menarche. ${ }^{23}$ Pada penelitian Moisan dkk. (1990) mendapatkan adanya hubungan antara konsumsi vitamin $\mathrm{C}$ dengan kejadian menarche, namun tidak menemukan hubungan yang signifikan antara konsumsi makronutrien (karbohidrat, lemak, protein) dengan kejadian menarche. ${ }^{10}$ Walaupun demikian beberapa penelitian melaporkan hubungan yang signifikan antara usia menarche dini dengan konsumsi makanan tinggi kalori $^{24,25,26}$, konsumsi tinggi lemak ${ }^{27}$, konsumsi tinggi protein ${ }^{28}$, atau konsumsi rendah serat ${ }^{29}$. Konsumsi daging yang tinggi juga dikaitkan dengan kejadian usia menarche dini, sementara pada subjek dengan diet vegetarian dihubungkan dengan keterlambatan usia menarche. ${ }^{30}$

Menurut angka kecukupan gizi yang dianjurkan, kebutuhan energi pada perempuan usia 10-19 berkisar antara 2000-2250 kkal, protein 56-60 gram, dan lemak 67-75 gram. ${ }^{31}$ Kelompok remaja 10-19 tahun merupakan kelompok usia peralihan dari anak-anak menjadi remaja muda sampai dewasa. Kondisi penting yang berpengaruh terhadap kebutuhan zat gizi kelompok ini adalah pertumbuhan cepat memasuki usia pubertas, kebiasaan jajan, menstruasi dan perhatian terhadap penampilan fisik citra tubuh (body image) pada remaja puteri. Dengan demikian perhitungan terhadap kebutuhan zat gizi pada kelompok ini harus memperhatikan kondisi-kondisi tersebut. Khusus pada remaja puteri, perhatian harus lebih ditekankan terhadap persiapan mereka sebelum menikah. ${ }^{32}$

Sejalan dengan hasil penelitian di atas perlu adanya upaya pemenuhan kebutuhan gizi pada remaja dini, khususnya remaja putri. Kebutuhan dan kecukupan zat gizi makro (karbohidrat, protein, lemak), dan zat gizi mikro (vitamin, mineral) sangat diperlukan bagi remaja putri. 
Penyuluhan gizi bagi remaja putri di sekolahsekolah terkait dengan pentingnya sarapan pagi, konsumsi sumber protein hewani (telur, ikan sungai, ikan laut) dan sumber protein nabati (tahu, tempe, kacang hijau, kacang merah) yang murah dan terjangkau, konsumsi buah-buahan dan sayuran, Hal ini sangat penting dalam rangka mencapai status gizi yang optimal untuk mempersiapkan pada tahap kehidupan berikutnya.

\section{KESIMPULAN}

Indeks massa tubuh berhubungan dengan usia menarche. Terjadi Tren penurunan usia menarche pada perempuan di Indonesia.

\section{SARAN}

Perlu upaya pemenuhan zat gizi pada remaja untuk mencapai status gizi yang optimal khususnya pada remaja putri. Pemenuhan kecukupan zat gizi makro dan zat gizi mikro pada remaja putri perlu diupayakan melalui konsumsi makanan sehari-hari yang cukup dan berkualitas. Upaya promosi pada remaja putri melalui sekolah terkait pemahaman tentang pentingnya sarapan pagi, konsumsi makanan sumber protein tinggi seperti: ikan laut, ikan tawar, tahu, tempe, dan konsumsi sumber vitamin dan mineral dengan banyak mengonsumsi sayur dan buah. Selain itu perlu adanya studi lanjutan tentang hubungan antara IMT, kebiasaan makan dengan usia menarche dengan desain kohor.

\section{UCAPAN TERIMA KASIH}

Ucapan terima kasih kami sampaikan kepada Kepala Badan Litbangkes yang telah memberi ijin penggunaan data penelitian ini.

\section{DAFTAR PUSTAKA}

1. Sloboda DM, Hart R, Doherty DA, Pennell CE, Hickey M. Age at menarche: Influences of prenatal and postnatal growth. J Clin Endocrinol Metab. 2007;92(1):46-50.

2. Thomas F, Renaud F, Benefice E, de Meeus T GJ. International variability of ages at menarche and menopause: Patterns and main determinants. Hum Biol.
2001;73:271-90.

3. Adair LS. Size at Birth Predicts Age at Menarche. Pediatrics [Internet]. 2001 [cited 2017 Dec 12]; Available from: https://pdfs.semanticscholar.org/74c7/b30c 3f4fdb39baa5737a459cad615d374c4b.pdf

4. Tam CS, De Zegher F, Garnett SP, Baur LA, Cowell CT. Opposing influences of prenatal and postnatal growth on the timing of menarche. J Clin Endocrinol Metab. 2006;91(11):4369-73.

5. Ong KK, Ahmed ML DD. Lessons from large population studies on timing and tempo of puberty (secular trends and relation to body size): The European trend. Eur trend Mol Cell Endocrinol [Internet]. 2006;254-255:8-12. Available from: https://www.sciencedirect.com/science/arti cle/abs/pii/S030372070600219X

6. Anderson SE MA. Interpreting the continued decline in the average age at menarche: Results from two nationally representative surveys of U.S. girls studied 10 years apart. J Pediatr [Internet]. 2005;147(6):753-60. Available from: https://www.sciencedirect.com/science/arti cle/abs/pii/S0022347605006827

7. Danker-Hopfe H. Menarcheal age in Europe. Am J Phys Anthropol. 1986;29(7 S):81-112.

8. Koo MM, Rohan TE, Jain M, McLaughlin JR, Corey PN. A cohort study of dietary fibre intake and menarche. Public Health Nutr. 2002;5(2):353-60.

9. Bratke H, Bruserud IS, Brannsether B, Aßmus J, Bjerknes R, Roelants $\mathrm{M}$, et al. Timing of menarche in Norwegian girls: Associations with body mass index, waist circumference and skinfold thickness. BMC Pediatr. 2017;17(1):1-6.

10. Moisan J, Meyer F, Gingras S. Diet and age at menarche. Cancer Causes Control. 1990;1(2):149-54.

11. Al-Sahab B, Ardern CI, Hamadeh MJ, Tamim H. Age at menarche in Canada: Results from the National Longitudinal Survey of Children \& Youth. BMC Public Health. 2010;10.

12. Parent AS, Teilmann G, Juul A, Skakkebaek NE, Toppari J, Bourguignon 
JP. The Timing of Normal Puberty and the Age Limits of Sexual Precocity: Variations around the World, Secular Trends, and Changes after Migration. Endocr Rev. 2003;24(5):668-93.

13. Tanner J. Foetus into man: physical growth from conception to maturity [Internet]. Rev. and e. California: Stanford Libraries; 1990. 280 p. Available from: https://searchworks.stanford.edu/view/909 8108

14. Brundtland GH WL. Menarcheal age in norway in the 19th century: A reevaluation of the historical sources. Ann Hum Biol [Internet]. 1976;3(4):363-74. Available from: https://www.tandfonline.com/doi/abs/10.1 080/03014467600001581

15. GS T. Cardiovascular disease risk factors related to sexual maturation: The Oslo youth study. J Chronic Dis [Internet]. 1985;38(8):633-42. Available from: https://www.sciencedirect.com/science/arti cle/pii/0021968185900177

16. Bratberg GH, Nilsen TIL, Holmen TL, Vatten LJ. Early sexual maturation, central adiposity and subsequent overweight in late adolescence. A four-year follow-up of 1605 adolescent Norwegian boys and girls: The Young HUNT study. BMC Public Health. 2007;7:1-7.

17. Aksglaede L, Sørensen K, Petersen JH, Skakkebæk NE, Juul A. Recent decline in age at breast development: The Copenhagen puberty study. Pediatrics. 2009; 123(5).

18. Talma H, Schönbeck $Y$, van Dommelen P, Bakker B, van Buuren S, HiraSing RA. Trends in Menarcheal Age between 1955 and 2009 in the Netherlands. PLoS One. 2013;8(4):1-7.

19. Salgin B, Norris SA, Prentice P, Pettifor JM, Richter LM, Ong KK, et al. Even transient rapid infancy weight gain is associated with higher BMI in young adults and earlier menarche. Int $\mathbf{J}$ Obes. 2015;39(6):939-44.

20. Stark O, Peckham CS, Moynihan C. Weight and age at menarche. Arch Dis Child. 1989;64(3):383-7.

21. Van Lenthe FJ, Kemper HCG, Van
Mechelen W. Rapid maturation in adolescence results in greater obesity in adulthood: The Amsterdam Growth and Health Study. Am J Clin Nutr. 1996;64(1):18-24.

22. Braithwaite D, Moore DH, Lustig RH, Epel ES, Ong KK, Rehkopf DH, et al. Socioeconomic status in relation to early menarche among black and white girls. Cancer Causes Control. 2009;20(5):71320.

23. Frisch RE MJ. Menstrual cycles: fatness as a determinant of minimum weight for height necessary for their maintenance or onset. Science (80- ) [Internet]. 1974;185(4155):949-51. Available from: https://www.ncbi.nlm.nih.gov/pubmed/446 9672

24. Moisan J, Meyer F GS. A NESTED CASE-CONTROL STUDY OF THE CORRELATES OF EARLY MENARCHE. Am J Epidemiol [Internet]. 1990;132(5). Available from: https://academic.oup.com/aje/articleabstract/132/5/953/88770

25. François Meyer;Jocelyne Moisan;Diane Marcoux;Claude Bouchard. Dietary and Physical Determinants of Menarche. Epidemiology [Internet]. 1990;1(5):377381. Available from: https://insights.ovid.com/epidemiology/epi de/1990/09/000/dietary-physicaldeterminants-menarche/7/00001648

26. Hill P, Wynder EL GL. Diet and menarche in different ethnic groups. Eur $\mathbf{J}$ cancer [Internet]. 1980;16(4):519-25. Available from:

https://www.sciencedirect.com/science/arti cle/abs/pii/0014296480902315

27. Richardson BD, Laing PM, RantshoJM SR. The bearing of diverse patterns of diet on growth and menarche in four ethnic groups of South African girls. J Trop Med Hyg [Internet]. 1983;86(1):5-12. Available from: https://www.ncbi.nlm.nih.gov/pubmed/685 4702

28. Sanchez A, Kissinger DG PR. A hypothesis on the etiological role of diet on age of menarche. MedHyp [Internet]. 1981;7(11):1339-45. Available from: https://www.ncbi.nlm.nih.gov/pubmed/732 
1920?dopt=Abstract

29. Hughes RE JE. Intake of dietary fibre and the age of menarche. Ann Hum Biol [Internet]. 1985;12(4):325-32. Available from:

https://www.ncbi.nlm.nih.gov/pubmed/299 4546

30. Kissinget DG SA. The association of dietary factors with the age of menarche.
Nutr Res [Internet]. 1987;7(5):471-9. Available from: https://www.sciencedirect.com/science/arti cle/pii/S0271531787800039

31. Kesehatan K. Permenkes RI No 75 tahun 2013. 2013.

32. Kesehatan K. Pedoman Gizi Seimbang. 2014. 